\title{
PENGARUH SKARIFIKASI PADA POLA IMBIBISI DAN PERKECAMBAHAN BENIH SAGA MANIS (Abruss precatorius L.)
}

\author{
Juhanda, Yayuk Nurmiaty \& Ermawati \\ Jurusan Agroteknologi, Fakultas Pertanian Universitas Lampung \\ Jl. Prof. Soemantri Brodjonegoro, No.1 Bandar Lampung 35145 \\ E-mail:putrabungsu8713@yahoo.co.id
}

\begin{abstract}
ABSTRAK
Penelitian ini bertujuan untuk mengetahui pengaruh skarifikasi pada pola imbibisi dan perkecambahan benih saga manis (Abruss precatorius $\mathrm{L}$.). Benih saga manis yang diberi perlakuan skarifikasi diduga memiliki pola imbibisi dan perkecambahan yang berbeda dibandingkan dengan benih saga manis tanpa skarifikasi. Penelitian ini telah dilakukan di Laboratorium Benih dan Pemuliaan Tanaman Universitas Lampung dari Pebruari 2012 sampai dengan Maret 2012. Normalitas data diuji menggunakan uji Kolmogorov-Smirnov/Shapiro-Wilk. Pengujian homogenitas ragam menggunakan uji F. Untuk menguji hipotesis komparatif dua sampel independen, menggunakan uji-t. Hasil penelitian disimpulkan bahwa (1) pola imbibisi dan perkecambahan benih saga manis yang diskarifikasi meningkat secara linier dari pelembaban 0-24 jam, pola ini konstan dari pelembaban 24-68 jam (2) perkecambahan benih saga manis yang diskarifikasi lebih tinggi dibandingkan dengan tanpa skarifikasi melalui peningkatan daya berkecambah, kecepatan berkecambah, keserempakan berkecambah, dan bobot kering kecambah normal.
\end{abstract}

Kata kunci: Dormansi benih, pola imbibisi, Saga manis, skarifikasi

\section{PENDAHULUAN}

Industri obat tradisional di Indonesia berkembang cukup pesat. Perkembangan industri obat yang pesat tercermin dari jumlah perusahaan obat sebagai pendukungnya. Permasalahan pengembangan industri obat tradisional adalah sebagian besar bahan baku (sekitar 80\%) masih mengandalkan hasil pemanenan dari hutan atau habitat alami, sisanya (20\%) berasal dari hasil budidaya secara tradisional (Hasanah dan Rusmin, 2006). Indonesia yang beriklim tropis merupakan negara dengan keanekaragaman hayati terbesar kedua di dunia setelah Brazil. Di Indonesia terdapat 25.000-30.000 spesies tanaman yang merupakan $80 \%$ dari jenis tanaman di dunia dan $90 \%$ dari jenis tanaman di Asia. Hasil inventarisasi yang dilakukan PT Eisai pada 1986 mendapatkan sekitar tujuh ribu spesies tanaman di Indonesia digunakan masyarakat sebagai obat, khususnya oleh industri jamu spesies yang didaftarkan ke Badan Pengawas Obat dan Makanan (BPOM) Republik Indonesia berjumlah 283 spesies tanaman. Departemen Kesehatan Republik Indonesia pada tahun 1986 mendokumentasi 940 tanaman obat dan jumlah tersebut tidak termasuk tanaman obat yang telah punah atau langka dan mungkin ada juga tanaman obat yang belum dicantumkan (Dewoto, 2007).

Saga manis merupakan tanaman obat asli Indonesia yang telah banyak dikenal luas oleh masyarakat umum. Saga manis yang pertumbuhannya merambat di pohon atau pagar, telah biasa ditanam oleh masyarakat (Purwantoro dan Roemantyo, 1993). Bagian tanaman yang banyak dimanfaatkan adalah daun dan biji. Beberapa manfaat tanaman saga yaitu dapat digunakan sebagai obat batuk, sariawan, bronchitis, amandel, sakit tenggorokan, peluruh kencing (deuretik), dan hepatitis (Wijayakusuma dan Dalimatha, 1998 yang dikutip oleh Ahmad, 2010).

Tanaman saga manis memiliki persentase benih dorman cukup tinggi. Dormansi benih terjadi karena sifat impermeabel kulit benih. Impermeabilitas benih saga manis disebabkan oleh kulit benih yang keras dan dilapisi oleh lapisan lilin sehingga kulit benih kedap terhadap air dan gas.

Skarifikasi merupakan salah satu upaya pretreatment atau perlakuan awal pada benih yang ditujukan untuk mematahkan dormansi dan mempercepat terjadinya perkecambahan benih yang seragam (Schmidt, 2000). Skarifikasi (pelukaan kulit benih) adalah cara untuk memberikan kondisi benih yang impermeabel menjadi permeabel melalui penusukan; pembakaran, pemecahan, pengikiran, dan penggoresan dengan bantuan pisau, jarum, pemotong kuku, kertas, amplas, dan alat lainnya (Schmidt, 2000). Kulit benih yang permeabel memungkinkan air dan gas dapat masuk ke dalam benih sehingga proses imbibisi dapat terjadi. Benih yang diskarifikasi akan menghasilkan proses 
imbibisi yang semakin baik. Air dan gas akan lebih cepat masuk ke dalam benih karena kulit benih yang permeabel. Air yang masuk ke dalam benih menyebabkan proses metabolisme dalam benih berjalan lebih cepat akibatnya perkecambahan yang dihasilkan akan semakin baik. Benih saga manis yang diskarifikasi diduga akan berkecambah lebih baik dibandingkan dengan benih yang tidak diskarifikasi. Kecambah normal yang dihasilkan dari benih yang diskarifikasi akan dihitung dan dibandingkan dengan benih saga manis yang tidak diskarifikasi. Tujuan penelitian ini adalah untuk mengetahui apakah pola imbibisi dan perkecambahan benih saga manis berbeda antara yang diskarifikasi dan tidak diskarifikasi.

\section{METODE PENELITIAN}

Penelitian ini dilaksanakan di Laboratorium Benih dan Pemuliaan Tanaman, Jurusan Budidaya Pertanian, Fakultas Pertanian, Universitas Lampung, Bandar Lampung pada Januari sampai Februari 2012.

Bahan-bahan yang digunakan dalam percobaan ini adalah benih saga manis yang dipanen pada tanggal 2 Januari 2012 dan telah mengalami masa penyimpanan selama tujuh minggu. Alat-alat yang digunakan adalah amplas halus, alat timbang elektrik Scout ${ }^{\mathrm{TM}}$ Pro $200 \mathrm{~g}$, termometer, erlenmeyer, pinset, pengukur waktu, kertas koran polos, alat pengecambah benih tipe IPB 73-2B, cawan petri, dan alat tulis.

Pada penelitian ini diterapkan dua perlakuan yaitu benih yang diskarifikasi dengan menggunakan amplas halus dan benih tanpa skarifikasi. Pengamplasan dilakukan pada kulit benih pada bagian cadangan makanan yang berwarna merah sampai kulit benih berwarna putih kekuning-kuningan. Masing-masing perlakuan diulang sebanyak sembilan kali. Variabel yang diamati pada penelitian ini yaitu imbibisi air, daya berkecambah, kecepatan berkecambah, keserempakan berkecambah, dan bobot kering kecambah normal. Untuk variabel imbibisi air, benih dengan masing-masing perlakuan dilembabkan pada kertas koran polos yang telah dibasahi dengan air. Pelembaban dilakukan selama 68 jam dan diamati setiap empat jam sekali dengan menimbang bobot benih yaitu pada $0,4,8,12$, dan seterusnya sampai benih mengembang penuh dan mulai muncul tanda-tanda keluarnya radikel. Penimbangan bobot benih dilakukan pada smua benih dalam setiap ulangan, dan diambil nilai rata-rata bobot dari semua ulangan. Untuk variabel perkecambahan diuji dengan metode uji kertas digulung didirikan dalam plastik (UKDDP) (ISTA, 2006). Pengamatan dan pengambilan data dilakukan pada semua satuan percobaan. Hal ini karena jumlah variabel dan satuan percobaan yang diamati sedikit.

Pengujian hipotesis komparatif dua sampel independen, menggunakan Uji-t. Pengujian homogenitas ragam dengan menggunakan uji F. Normalitas data diuji menggunakan uji Kolmogorov-Smirnov/Shapiro-Wilk. Hipotesis yang diajukan untuk uji homogenitas ragam adalah $\mathrm{H}_{0}$ bila ragam antara yang diskarifiksi dan tidak diskarifikasi homogen, sedangkan $\mathrm{H}_{1}$ bila ragam antara yang diskarifikasi dan tidak diskarifikasi tidak homogen. Bila $\mathrm{F}$ hitung d" $\mathrm{F}$ tabel, maka $\mathrm{H}_{0}$ diterima yang berarti ragam homogen; sedangkan hasil uji homogenitas ragam tersebut homogen bila $\mathrm{F}$ hitung $>\mathrm{F}$ tabel, maka $\mathrm{H}_{0}$ ditolak dan terima $\mathrm{H}_{1}$ yang berarti ragam tidak homogen. Ragam homogen mengunakan Uji-t dengan derajat kebebasan $(\mathrm{dk})=\mathrm{n}_{1}+\mathrm{n}_{2}-2$, bila ragam tidak homogen, maka uji t pada derajat kebebasan $\mathrm{dk}_{1}=\mathrm{n}_{1}-1$ atau $\mathrm{dk}_{2}$ $=\mathrm{n}_{2}-1$.

\section{HASIL DAN PEMBAHASAN}

Hasil penelitian menunjukkan bahwa perlakuan skarifikasi mekanik lebih baik dalam menghasilkan perkecambahan benih saga manis (Abrus precatorius L.) yang ditunjukkan oleh setiap peubah yang diamati yaitu daya berkecambah, kecepatan berkecambah, keserempakan berkecambah, dan bobot kering kecambah normal. Hasil penelitian menunjukkan bahwa skarifikasi mekanik menggunakan amplas memberikan pengaruh yang nyata pada semua peubah yang diamati (Tabel 1).

Daya berkecambah, kecepatan berkecambah, keserempakan berkecambah, dan bobot kering kecambah normal dari benih saga manis yang diskarifikasi menggunakan amplas lebih tinggi daripada tanpa skarifikasi (Tabel 1).

Laju imbibisi benih yang telah dilembabkan sampai 68 jam yang mendapat perlakuan skarifikasi mekanik dengan diamplas menunjukkan bobot benih lebih tinggi dibandingkan dengan benih yang tidak diberi perlakuan skarifikasi. Laju imbibisi benih saga manis yang diskarifikasi mekanik menunjukkan bobot benih meningkat secara linier setelah dilembabkan sampai 24 jam (Gambar 1). Lebih lanjut dihasilkan bahwa benih yang telah dilembabkan lebih dari 24 jam sampai 68 jam, laju imbibisi cenderung konstan (Gambar 1). Laju imbibisi benih saga manis tanpa diskarifikasi dan telah dilembabkan sampai 68 jam menunjukkan bobot benih yang konstan (stabil) (Gambar 1).

Hasil penelitian menunjukkan bahwa benih saga manis yang diskarifikasi mekanik dengan diamplas menghasilkan laju imbibisi yang berbeda dibandingkan 
Tabel 1. Rekapitulasi hasil Uji-t untuk pengaruh cara skarifikasi pada perkecambahan benih saga manis

\begin{tabular}{|c|c|c|c|c|c|c|}
\hline Variabel & Perlakuan & $\mathrm{dk}$ & $\mathrm{N}$ & Rata-rata & t-hitung & t-tabel \\
\hline $\mathrm{Db}(\%)$ & $\begin{array}{l}\text { Kontrol } \\
\text { Amplas }\end{array}$ & $\begin{array}{l}16 \\
16\end{array}$ & $\begin{array}{l}9 \\
9\end{array}$ & $\begin{array}{l}11,78 \\
87,56\end{array}$ & $27,73^{*}$ & 1,75 \\
\hline Kcb (\%/hari) & $\begin{array}{l}\text { Kontrol } \\
\text { Amplas }\end{array}$ & $\begin{array}{l}8 \\
8\end{array}$ & $\begin{array}{l}9 \\
9\end{array}$ & $\begin{array}{r}0,93 \\
14,19\end{array}$ & $19,56^{*}$ & 1,86 \\
\hline $\mathrm{Ksp}(\%)$ & $\begin{array}{l}\text { Kontrol } \\
\text { Amplas }\end{array}$ & $\begin{array}{l}8 \\
8\end{array}$ & $\begin{array}{l}9 \\
9\end{array}$ & $\begin{array}{r}5,78 \\
81,78\end{array}$ & $23,97^{*}$ & 1,86 \\
\hline Bkkn (g) & $\begin{array}{l}\text { Kontrol } \\
\text { Amplas }\end{array}$ & $\begin{array}{l}8 \\
8\end{array}$ & $\begin{array}{l}9 \\
9\end{array}$ & $\begin{array}{l}0,42 \\
0,74\end{array}$ & $5,04 *$ & 1,86 \\
\hline
\end{tabular}

Keterangan: Db (daya berkecambah), Kcb (kecepatan berkecambah), Ksp (keserempakan berkecambah), Bkkn (bobot kering kecambah normal), dk (derajat kebebasan), dan * (berbeda pada $\alpha_{0,05}$ ).

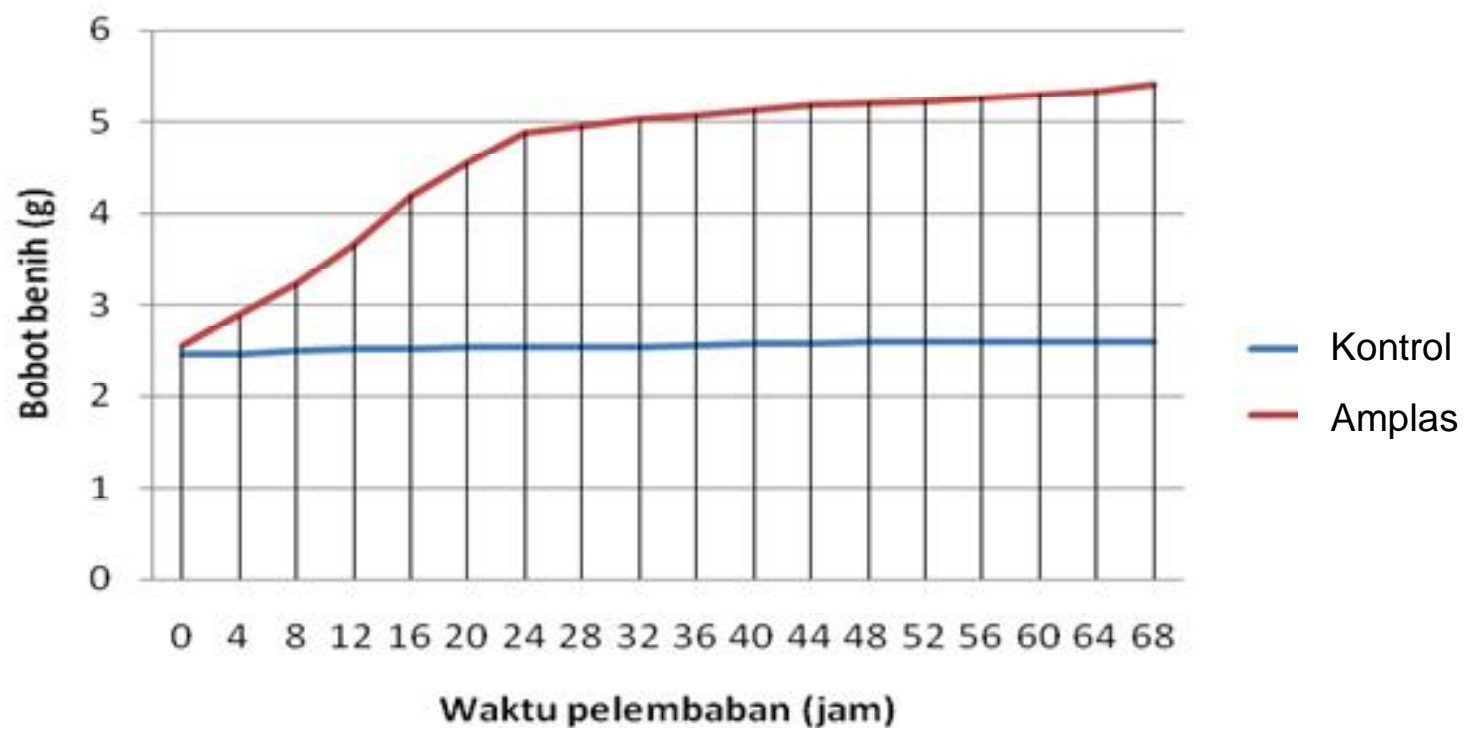

Gambar 1. Laju imbibisi benih Saga manis pada pelembaban selama 68 jam.

dengan benih saga manis tanpa skarifikasi setelah dilembabkan sampai 68 jam. Laju imbibisi terus mengalami peningkatan secara linier sampai pelembaban selama 24 jam, selanjutnya imbibisi mulai konstan (stabil) sampai 68 jam (Gambar 1). Secara umum benih mengalami tiga fase penyerapan air yaitu fase penyerapan cepat, fase penyerapan lambat, dan fase penyerapan aktif.

Tanaman saga manis termasuk dalam famili Leguminoceae yang diperbanyak dengan benih. Menurut Schmidt (2000), benih tanaman legum pada umumnya mengalami dormansi fisik yang disebabkan oleh morfologis kulit benih yang menyebabkan kulit benih bersifat impermeabel. Kulit benih saga manis yang bersifat impermeabel menyebabkan benih tidak dapat berimbibisi terlihat dari pola imbibisi yang tidak diskarifikasi. Dalam penelitian ini pematahan sifat dorman pada benih saga manis dilakukan dengan cara skarifikasi mekanik dengan diamplas. Skarifikasi mekanik dengan amplas dilakukan pada bagian kulit cadangan makanan yang berwarna merah menyebabkan benih bersifat permeabel sehingga air dapat masuk ke dalam benih yang diskarifikasi.

Benih saga manis yang diberi perlakuan skarifikasi mekanik menghasilkan laju imbibisi yang baik, laju imbibisi meningkat secara linier sampai pelembaban 24 jam, juga diikuti pada peningkatan bobot benih. Penyerapan air setelah 24 jam sampai 68 jam konstan. Pola penyerapan air ini didukung oleh pendapat Bewley dan Black (2006) yaitu penyerapan air dimulai dari 
proses imbibisi (fase I) sampai 24 jam yang merupakan fase penyerapan cepat dan diikuti oleh (fase II) yang ditandai dengan penyerapan air yang cenderung konstan 24 “ 68 jam. Dengan laju imbibisi yang baik menyebabkan kebutuhan air untuk benih terpenuhi sehingga proses metabolisme benih dapat berjalan dengan baik. Proses metabolisme benih yang baik menyebabkan terjadinya perkecambahan yang baik. Skarifikasi menyebabkan terjadinya peningkatan permeabilitas kulit benih sehingga laju imbibisi benih tinggi. Laju imbibisi yang tinggi diikuti dengan penguraian cadangan makanan yang tinggi, hal ini ditunjukkan oleh variabel perkecambahan yang diamati seperti daya berkecambah, kecepatan berkecambah, dan keserempakan berkecambah (Tabel 1). Peningkatan perkecambahan benih saga manis yang diskarifikasi dapat dibuktikan dengan nilai bobot kering kecambah normal yang meningkat (Tabel 1).

Hal ini berarti dengan proses metabolisme yang baik akan menghasilkan perkecambahan yang baik karena benih yang berkecambah dapat memanfaatkan cadangan makanan dalam benih dengan baik. Dengan adanya air, oksigen akan masuk ke dalam benih dan mengurai cadangan makanan yang digunakan sebagai sumber energi untuk pertumbuhan kecambah normal dalam waktu yang cepat dan serentak. Hal ini ditunjukkan dari hasil benih saga manis yang diskarifikasi mengalami perkecambahan yang meningkat. Peningkatan perkecambahan dapat dilihat pada variabel perkecambahan yang diamati yaitu daya berkecambah, kecepatan berkecambah, keserempakan berkecambah, dan bobot kering kecambah normal. Menurut Yuniarti (2002), untuk benih saga dengan perlakuan dikikir kemudian direndam dalam air dingin selama 24 jam, dapat menghasilkan nilai daya berkecambah cukup tinggi yaitu sebesar 77,33\%. Hal ini berarti bahwa perendaman dalam air dingin selama 24 jam setelah pengikiran benih dapat merangsang perkecambahan benih saga pohon. Hasanah dan Rusmin (2006) menyatakan bahwa dormansi benih saga dapat dipecahkan dengan perlakuan skarifikasi dengan pengikisan kulit benih.Dengan perlakuan tersebut, daya berkecambah benih dapat mencapai $97 \%$ dibandingkan kontrol hanya $6 \%$.

Benih saga manis tanpa skarifikasi tidak mengalami peningkatan bobot benih setelah dilembabkan sampai 68 jam. Bobot benih cenderung konstan (stabil) sampai pada pelembaban 68 jam (Gambar 1). Hasil ini membuktikan bahwa benih saga manis mengalami dormansi kulit benih. Benih saga manis tanpa skarifikasi tidak mengalami peningkatan laju imbibisi setelah dilembabkan selama 68 jam karena sifat kulit benih yang masih tetap impermeabel, sehingga air dan gas tidak dapat masuk kedalam benih. Menurut Schmidt (2000), impermeabilitas benih legum disebabkan oleh dua lapisan paling luar kulit benih yaitu kutikula dan palisade. Kutikula adalah lapisan paling luar yang berlilin dan bersifat menolak air sedangkan palisade merupakan lapisan yang terdiri dari sel-sel yang panjang, sempit, terbungkus rapat, dan vertikal sehingga sulit untuk dilewati air. Benih saga manis tanpa diskarifikasi cenderung memiliki laju imbibisi yang konstan (stabil).

Laju imbibisi yang terjadi setelah benih dilembabkan selama 68 jam sangat rendah sehingga kebutuhan air benih tidak terpenuhi. Rendahnya laju imbibisi pada benih saga manis tanpa diskarifikasi disebabkan oleh sifat kulit benih saga manis yang masih impermeabel, sehingga air dan gas tidak dapat masuk ke dalam benih. Air tidak masuk ke dalam benih menyebabkan proses metabolisme benih tidak berjalan dengan baik. Proses metabolisme benih yang kurang baik menyebabkan persentase perkecambahan benih saga manis rendah, hal ini ditunjukkan oleh rendahnya nilai variabel perkecambahan yang diamati yaitu daya berkecambah, kecepatan berkecambah, dan keserempakan bekecambah. Nilai perkecambahan benih saga manis tanpa skarifikasi yang rendah juga dibuktikan oleh rendahnya nilai bobot kering kecambah normal yang rendah (Tabel 1).

\section{KESIMPULAN}

Pola imbibisi dan perkecambahan benih saga manis yang diskarifikasi meningkat secara linier sampai pola ini konstan pada pelembaban 24-68 jam. Perkecambahan benih saga manis yang diskarifikasi lebih tinggi dibandingkan dengan tanpa skarifikasi melalui peningkatan daya berkecambah, kecepatan berkecambah, keserempakan berkecambah, dan bobot kering kecambah normal.

\section{DAFTAR PUSTAKA}

Ahmad, I. N. 2010. Pembuatan tablet hisap ekstrak etanolik daun saga (Abrus precatorius $\mathrm{L}$.) dengan amilum manihot sebagai bahan pengikat menggunakan metoda granulasi basah. Skripsi. Universitas Muhamadiyah. Surakarta. $59 \mathrm{hlm}$.

Bewley, J.D. and M. Black. 2006. Seeds, Physiology of Development And Germination. Plenum Press. New York. 367 p.

Copeland, L.O. and M.B. McDonald. 2001. Principles of Seed Science and Technology. Kluwer Academic Publishers. 467 p. 
Dewoto, H.R. 2007. Pengembangan obat tradisional di Indonesia menjadi fitofarmaka. Departemen Farmakologi Fakultas Kedokteran. Universitas Indonesia. Majalah Kedokteran Indonesia. 57(7): $205-211$.

Hasanah, M. dan D. Rusmin. 2006. Teknologi pengelolaan benih beberapa tanaman obat di Indonesia. Balai penelitian tanaman obat dan aromatik.Jurnal Litbang Pertanian. 25(2):69-70.

ISTA. 2006. International Rules for Seed Testing. The International Seed Testing Association. Bassersdorf. CH-. Switzerland. 397 p.
Purwantoro, R.S. dan Roemantyo. 1993. Konservasi tempuyung dan saga manis suatu studi Kebun Raya Bogor. Jurnal Warta Tumbuhan Obat Indonesia, Pusat Penelitian dan Pengembangan Farmasi. 2(2): $18-20$.

Schmidt, L. 2000. Pedoman Penanganan Benih Tanaman Hutan Tropis dan Subtropis. Diterjemahkan oleh Direktorat Jendral Rehabilitasi Lahan dan Perhutanan Sosial Departemen Kehutanan. PT Gramedia. Jakarta. 530 hlm.

Yuniarti, N. 2002. Penentuan cara perlakuan pendahuluan benih saga pohon. Jurnal Manajemen Hutan Tropika. 8(2): 97-101. 